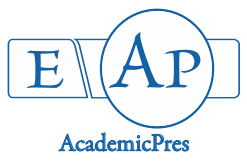

\author{
Daudu YOA et al. (2021) \\ Notulae Scientia Biologicae 13(1):10876 \\ DOI: $10.15835 / \mathrm{nsb} 13110876$ \\ Research Article
}

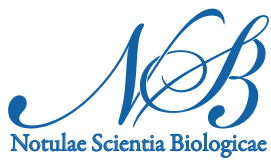

\title{
Aqueous seed extracts of Jimson weed (Datura stramonium L.) stimulate morpho-agronomic attributes in selected soybean [Glycine max (L.) Merr.] varieties
}

\section{Yusuf O.A. DAUDU, Olamide A. FALUSI, Abdulhakeem ABUBAKAR*, Ibrahim A. SALIHU, Shaibu O. OTARU, Muflihah A. UMAR}

\author{
Federal University of Technology, School of Life Sciences, Department of Plant Biology, PMB 64, Minna, Nigeria; \\ dauduoladipupoyusuf@yahoo.com; falusiolamide@gmail.com; abuakim2007@gmail.com (*corresponding author); \\ siaattahiru@yahoo.com; otaru.opata@yahoo.com;umarmuflihah@gmail.com
}

\begin{abstract}
Datura stramonium (L.) contains allelochemicals capable of affecting agro-morphological traits in plants. Thus, field experiment was carried out at Upper Niger River Basin Development Authority, Minna, Nigeria to examine the effects of different concentrations [25\%, 50\% and $100 \%$ and $0 \%$ (control)] of $D$. stramonium aqueous seed extracts on agro-morphological attributes of two soybean varieties ('TG x 2018-5E' and 'TG x 2022-4E'), obtained from International Institute of Tropical Agriculture, Ibadan. Dry seeds of the soybean were pre-soaked in the Datura seed extracts for two hours before planting in a complete randomized block design (CRBD) with three replicates each. Data obtained were subjected to analysis of variance (ANOVA). At maturity, D. stramonium seed extracts significantly $(\mathrm{P} \leq 0.05)$ increased plant height (38.37 $\mathrm{cm}$ ) and length of petiole $(2.93 \mathrm{~cm})$ for 'TG x 2018-5E' at $100 \%$ concentration. Significantly highest plant height $(29.20 \mathrm{~cm})$ and number of branches $(17.00)$ were enhanced in 'TG x 2022-4E' at $50 \%$ concentration. Both 'TG x 2018-5E' and 'TG x 2022-4E' leaf areas were significantly highest $\left(23.11 \mathrm{~cm}^{2}\right.$ and $28.41 \mathrm{~cm}^{2}$, respectively) at $100 \%$ concentration. Yield attributes such as number of seeds per plant, weight of fresh and dry pods per plant for both 'TG x 2018-5E' (3.33, 1.60 and 1.32, respectively) and 'TG x 2022-4E' (3.00, 0.60 and 0.26 , respectively) were significantly stimulated in $50 \%$ concentration while number of pods per plant was significantly highest for 'TG $\mathrm{x} 2018-5 \mathrm{E}$ ' and 'TG $\mathrm{x} 2022-4 \mathrm{E}$ ' (3.33 and 3.00, respectively) in $100 \%$ concentration. On these premises higher concentrations (50\% and 100\%) of D. stramonium seed extracts support better morphological growth and yield characters in soybean varieties.
\end{abstract}

Keywords: agro-morphological; allelochemicals; seed extracts; soybean; stimulatory effects

\section{Introduction}

Datura stramonium (Jimson weed) is an annual poisonous, alkaloid containing plant from the nightshade family (Solanaceae). It is also called Angel's trumpet, Thorn apple, Stinkweed, Devil's trumpet, Jamestown weed, Locoweed and Hell's bells (Mahnaz et al., 2012). D. stramonium originates in the America's but is now found around the world including the warmer regions of North, Central and South America,

Received: O1 Jan 2021. Received in revised form: 29 Jan 2021. Accepted: O2 Feb 2021. Published online: 03 Feb 2021.

From Volume 13, Issue 1, 2021, Notulae Scientia Biologicae journal will use article numbers in place of the traditional method of continuous pagination through the volume. 
Europe, Asia, and Africa (Tamiru et al., 2016). The large shrubs can grow to $1.2 \mathrm{~m}$ high, the leaves are $20 \mathrm{~cm}$ long, ovate and dark green in colour. The flowers are large, showy, white and terminal; the corolla is funnel shaped and folded with a short-5- sectioned border, there are 5 stamens and superior ovary. It is classified under division Magnoliophyta, order Solanales, and genus Datura (Ganesh et al., 2015). The plant is rich in tropane alkaloids such as scopolamine (hyocine), hyoscyamine (duboisine) and atropine (daturin) present in their seeds and flowers. Scopolamine has been reported in higher concentration than hyoscyamine in all varieties of Datura (Hiraoka, 1996). The seeds show the highest alkaloid content (Alkaloids are naturally occurring compounds containing one or more nitrogen atoms). These alkylating agents act as chemical mutagens to plants, thereby hindering, altering or stimulating its growth. D. stramonium contains allelochemicals which inhibits growth of associated plant species through allelopathic mechanisms and very rich in alkaloids (Maibam et al., 2011). Some plants are known to have inhibitory effects on seeds germination and seedling growth of other neighbouring plants by either releasing allelopathic substances as exudates from living plant tissues or through decomposition of plant residues (Alexander et al., 2008; Maibam et al., 2008; Oseni et al., 2011; Butnariu, 2012). Some of these chemicals produced by allelopathic plants could act as chemical mutagens on some plants; the release of these allelochemicals by this plant affects the survival of other plants. Datura as an allelopathic plants could release allelochemicals which have negative effects on leaf chlorophyll of neighbouring plant species (Oyerinde et al., 2009). Such allelochemicals that are released to the environment by poisonous plant species have significant effects on neighbouring plants by reducing the rate of photosynthesis and respiration processes (Gniazdowska and Bgatek, 2005).

The soybean or soya bean [ Glycine $\max (\mathrm{L})$ Merr.] is a leguminous vegetable of the pea family (Fabaceae) that grows in tropical, subtropical, and temperate climates. The plant is classed as an oilseed rather than a pulse by the UN food and Agricultural Organization (FAO, 1994). Soybean is an important crop produced mainly in the guinea savannah zone of Nigeria. However, it was reported that the crop is grown in rather small holder farms in most African countries including Nigeria (Olorunsanya et al., 2009); the crop has been successfully grown in many states in Nigeria using low agricultural import (Adekunle et al., 2005). It can be used as food for both man and animal as well as industrial purposes.

Some plant extracts are known to cause alteration (i.e. mutation) in cells of other plants thereby causing variations in their normal growth and yield attributes. An example of plant extracts used as a mutagen is Colchicine which is a toxic and secondary metabolite obtained from bulbs and seeds of Autumn crocus (Colchicum autumnale), it prevents microtubule formation and doubles the number of chromosomes thereby inducing polyploidy in plants. Thus, it is based on this premise that effects of $D$. stramonium aqueous seed extracts are examined on selected soybeans varieties in Minna, Nigeria as an alternative source of biological mutagen.

\section{Materials and Methods}

\section{Collection of experimental materials}

Two varieties of soybeans ('TG x 2018-5E' and 'TG x 2022-4E') were obtained from International Institute of Tropical Agriculture (IITA), Ibadan, Oyo state. The seeds of D. stramonium were collected along the bush of challawa industrial estate, Kano State, Nigeria.

Preparation of test material (Datura seed extract) and treatment of soybean seeds

A modified method of Stef et al. (2018) was used for the extraction of the phytochemicals in the Jimson weed seeds. The seeds of $D$. stramonium collected were air dried and then powdered; 50 grams of the powdered sample was weighed mixed with $500 \mathrm{ml}$ of distilled water in a conical flask with the mouth sealed. These were put into a magnetic stirrer for 24 hours, after which filtration was performed. All the extracts were filtered using Muslin cloth and stored in a glass container at $4{ }^{\circ} \mathrm{C}$ for use later. From this stock solution, with concentration 
of $0.1 \mathrm{~g} / \mathrm{ml}(100 \%)$, two additional extract concentrations were made (25\% and $50 \%)$. A dilution formula $(\mathrm{C} 1 \mathrm{~V} 1=\mathrm{C} 2 \mathrm{~V} 2)$ was used to obtain the other concentrations; where $\mathrm{C} 1$ and $\mathrm{V} 1$ are the concentration and volume of the stock solution respectively and $\mathrm{C} 2$ and V2 are the respective concentration and volume of new attributed solution. Twenty seeds of soybean of each hybrid variety were treated with different concentration of seeds extract prepared from $D$. stramonium for 2 hours.

\section{Experimental site and experimental design}

The experiment was conducted at the field of Upper Niger River Basin Development Authority (UNRBDA), Tudun Fulani, Minna, Niger State. The experimental field was ploughed, harrowed and ridged; each plot row consists of $2 \mathrm{~m}$ long with inter row spacing of $0.75 \mathrm{~m}$. Three seeds of each treatments (control, 25,50 and $100 \%$ ) were sown per hole in a randomized complete block design (RCBD) with three replicates each. The seedlings were later thinned to one seedling per hole at three to four weeks after planting.

\section{Measurement of morphological and yield parameters}

The quantitative parameters collected from the experimental field include; plant height, number of branches per plant, length of petiole, leaf area, number of pods per plant, number of seeds per pod, length of pods, weight of fresh pods after harvest and weight of dry pods in each treated soybean plants for each variety following the method of Filemon et al. (2013) and Daudu et al. (2020). This was done using a metre rule and digital measuring scale.

\section{Data analysis}

The obtained data were pooled for analysis of variance (ANOVA), to test for significant different among the treatments. Post hoc was done using Duncan's multiple range test (DMRT) to separate the means where there were differences. Pearson's linear correlation was used to determine relationship among some of the parameters. All values were considered significant at $\mathrm{P} \leq 0.05$.

\section{Results}

The results of the effects of aqueous seed extracts of Jimson weed on two varieties of soybean showed that the extracts affected the morphological traits of the crop in varying ways. Different concentrations of the extracts affected the soybean varieties in different ways. The $100 \%$ concentration produced significantly $(\mathrm{P} \leq$ 0.05 ) highest plant height in 'TG x 2018-5E' $(38.37 \mathrm{~cm})$ at maturity; however, in 'TG x 2022-4E', the 50\% concentration produced significantly $(\mathrm{P} \leq 0.05)$ highest plant height $(29.20 \mathrm{~cm})$ at maturity (Table 1$)$. Similarly, the $100 \%$ concentration produced the highest $(2.93 \mathrm{~cm})$ petiole length at maturity in 'TG x 2018$5 E^{\prime}$; this value was significantly the same $(P>0.05)$ with $25 \%$ concentration $(2.63 \mathrm{~cm})$ and $50 \%$ concentration $(2.77 \mathrm{~cm})$ but significantly different $(\mathrm{P} \leq 0.05)$ from the control $(2.50 \mathrm{~cm})$. However, the highest petiole length $(2.37 \mathrm{~cm})$ was due to the control at maturity in 'TG x 2022-4E'; this value was significantly different from $25 \%$ concentration $(1.57 \mathrm{~cm})$, but not significant $(\mathrm{P}>0.05)$ to $50 \%(2.23 \mathrm{~cm})$ and $100 \%$ concentration $(2.30 \mathrm{~cm})$ (Table 1). For the leaf areas at maturity, $100 \%$ concentration of the extract produced significantly highest leaf area $\left(23.11 \mathrm{~cm}^{2}\right)$ in 'TG $x$ 2018-5E' and $\left(28.41 \mathrm{~cm}^{2}\right)$ in 'TG $\times 2022-4 \mathrm{E}$ '. For the number of branches per plant at maturity, $50 \%$ concentration produced the mean highest number of branches (16.33) in 'TG x 2018-5E', although this value was not significantly different $(\mathrm{P}>0.05)$ from the other concentrations. Similarly, 50\% concentration produced the mean highest number of branches (17.00) in 'TG x 2022-4E'; this value was significantly different from the control (12.67) and all the other values (Table 1). 
Daudu YOA et al. (2020). Not Sci Biol 13(1):10876

Table 1. Effects of Datura aqueous seed extracts on morphological traits of soybean varieties at maturity

\begin{tabular}{|c|c|c|c|c|}
\hline Treatment & $\begin{array}{c}\text { Plant height } \\
(\mathrm{cm})\end{array}$ & $\begin{array}{c}\text { Length of petiole } \\
(\mathrm{cm})\end{array}$ & $\begin{array}{c}\text { Leaf area } \\
\left(\mathrm{cm}^{2}\right)\end{array}$ & $\begin{array}{c}\text { Number of branches/ } \\
\text { plants }\end{array}$ \\
\hline \multicolumn{5}{|c|}{ 'TGx 2018-5E' } \\
\hline Control $(0 \%)$ & $28.97 \pm 1.25 \mathrm{a}$ & $2.50 \pm 0.10 \mathrm{a}$ & $19.89 \pm 2.64 \mathrm{a}$ & $13.00 \pm 1.73 \mathrm{a}$ \\
\hline $25 \%$ & $35.93 \pm 1.67 \mathrm{~b}$ & $2.63 \pm 0.09 \mathrm{~b}$ & $18.65 \pm 4.75 \mathrm{a}$ & $13.00 \pm 1.15 \mathrm{a}$ \\
\hline $50 \%$ & $27.70 \pm 3.06 \mathrm{a}$ & $2.77 \pm 0.18 \mathrm{~b}$ & $18.17 \pm 2.75 \mathrm{a}$ & $16.33 \pm 2.03 \mathrm{a}$ \\
\hline $100 \%$ & $38.37 \pm 5.58 \mathrm{~b}$ & $2.93 \pm 0.09 \mathrm{~b}$ & $23.11 \pm 3.06 \mathrm{~b}$ & $15.33 \pm 1.76 \mathrm{a}$ \\
\hline Total & 32.74 & 2.71 & 19.96 & 14.42 \\
\hline \multicolumn{5}{|c|}{ 'TGx 2022-4E' } \\
\hline Control $(0 \%)$ & $26.57 \pm 1.39 \mathrm{c}$ & $2.37 \pm 0.22 \mathrm{~b}$ & $17.19 \pm 1.73 \mathrm{a}$ & $12.67 \pm 1.76 \mathrm{a}$ \\
\hline $25 \%$ & $24.27 \pm 0.69 \mathrm{~b}$ & $1.57 \pm 0.13 \mathrm{a}$ & $15.50 \pm 1.49 \mathrm{a}$ & $14.33 \pm 0.88 \mathrm{ab}$ \\
\hline $50 \%$ & $29.20 \pm 1.19 \mathrm{~d}$ & $2.23 \pm 0.19 \mathrm{~b}$ & $24.97 \pm 1.66 \mathrm{~b}$ & $17.00 \pm 1.15 \mathrm{~b}$ \\
\hline $100 \%$ & $20.87 \pm 0.82 \mathrm{a}$ & $2.30 \pm 0.15 \mathrm{~b}$ & $28.41 \pm 2.94 \mathrm{~b}$ & $13.33 \pm 0.88 \mathrm{a}$ \\
\hline Total & 25.23 & 2.12 & 21.52 & 14.33 \\
\hline
\end{tabular}

Values are mean \pm Standard Error, values followed by the same alphabet(s) along the column are not significantly different at $\mathrm{p}>0.05$.

The aqueous leaf extracts of Jimson weed also affected the yield attributes of the soybean varieties in different ways. In 'TG x 2018-5E', the highest mean number of pods per plant was produced by $100 \%$ concentration (19.33), although the value was significantly the same $(P>0.05)$ with all other values. Similarly, in 'TG x 2022-4E', 100\% concentration produced the highest number of pods per plant (20.33); this value was significantly the same with the $50 \%$ concentration $(18.00)$ but significantly different $(\mathrm{P} \leq 0.05)$ from the control (10.67) and 25\% concentration (Table 2). Number of seeds per pod in 'TG x 2018-5E' was highest in $50 \%$ concentration (3.33), however, there was no significant difference from all the other treatments. Similar trend was observed in 'TG x 2022-4E', where $50 \%$ concentration produced the highest number of seeds per pod (3.00) but it was not significantly different from all the other values. Highest length of pods $(4.80 \mathrm{~cm})$ was produced by $100 \%$ concentration, this value was significantly higher than all the other values. However, the highest length of pod in 'TG x 2022-4E' was produced by the control $(3.73 \mathrm{~cm})$, although the value was significantly the same with all the other treatments (Table 2). Significantly highest weight of pod $(1.60 \mathrm{~g})$ was produced by $50 \%$ concentration in 'TG x 2018-5E'; similarly, in 'TG x 2022-4E', 50\% concentration produced the highest weight of pod $(0.65 \mathrm{~g})$, this value was significantly different from all the other treatments. Similar trend was observed for the weight of dry pod in 'TG x 2018-5E' and 'TG x 2022-4E'; the highest dry weight in 'TG $x$ 2018-5E' ( $1.32 \mathrm{~g}$ ) was produced by $50 \%$ concentration; this value was significantly different from all the other values. Highest dry weight in 'TG x 2022-4E' (0.26 g) was produced by $50 \%$ concentration; however, there is no significant difference $(\mathrm{P}>0.05)$ between this value and the other values (Table 2 ).

Pearson's linear correlation for 'TG x 2018-5E' revealed that number of branches at maturity was positively significant $(\mathrm{P} \leq 0.05)$ and moderately correlated with number of pods per plant $(0.527)$ and number of seeds per pod (0.610). Similarly, weight of dry pod was positively significant and moderately correlated with number of seeds per pod (0.593); meanwhile, weight of dry pod was positively significant and highly correlated with weight of fresh pod $(\mathrm{r}=0.748, \mathrm{P} \leq 0.01)$. This implies that these characters are linearly associated with one another (Table 3 ). 
Table 2. Effects of Datura aqueous seed extracts on yield attributes of soybean varieties

\begin{tabular}{|c|c|c|c|c|c|}
\hline Treatments & $\begin{array}{c}\text { Number of pods } \\
\text { per plant }\end{array}$ & $\begin{array}{c}\text { Number of } \\
\text { seeds per pod }\end{array}$ & $\begin{array}{l}\text { Length of pods } \\
(\mathrm{cm})\end{array}$ & $\begin{array}{l}\text { Weight of fresh } \\
\text { pod }(\mathrm{g})\end{array}$ & $\begin{array}{l}\text { Weight of dry } \\
\operatorname{pod}(\mathrm{g})\end{array}$ \\
\hline \multicolumn{6}{|c|}{ 'TG x 2018-5E' } \\
\hline Control (0\%) & $18.67 \pm 4.81 \mathrm{a}$ & $2.67 \pm 0.33 a$ & $4.37 \pm 0.33 \mathrm{ab}$ & $0.65 \pm 0.79 a$ & $0.27 \pm 0.02 \mathrm{a}$ \\
\hline $25 \%$ & $13.67 \pm 3.93 a$ & $2.33 \pm 0.33 a$ & $3.57 \pm 0.35 \mathrm{a}$ & $0.69 \pm 0.14 \mathrm{a}$ & $0.27 \pm 0.04 a$ \\
\hline $50 \%$ & $17.33 \pm 3.71 \mathrm{a}$ & $3.33 \pm 0.33 a$ & $4.40 \pm 0.25 \mathrm{ab}$ & $1.60 \pm 0.06 \mathrm{~b}$ & $1.32 \pm 0.13 b$ \\
\hline $100 \%$ & $19.33 \pm 1.67 \mathrm{a}$ & $2.67 \pm 0.33 a$ & $4.80 \pm 0.12 b$ & $0.66 \pm 0.06 a$ & $0.38 \pm 0.07 a$ \\
\hline Total & 17.25 & 2.75 & 4.28 & 0.76 & 0.56 \\
\hline \multicolumn{6}{|c|}{ 'TG x 2022-4E' } \\
\hline Control (0\%) & $10.67 \pm 0.67 \mathrm{a}$ & $2.67 \pm 0.33 a$ & $3.73 \pm 0.22 \mathrm{a}$ & $0.28 \pm 0.02 \mathrm{a}$ & $0.23 \pm 0.04 a$ \\
\hline $25 \%$ & $8.33 \pm 0.88 a$ & $2.33 \pm 0.33 a$ & $3.23 \pm 0.15 \mathrm{a}$ & $0.25 \pm 0.05 a$ & $0.21 \pm 0.05 a$ \\
\hline $50 \%$ & $18.00 \pm 2.89 \mathrm{~b}$ & $3.00 \pm 0.00 \mathrm{a}$ & $3.60 \pm 0.06 \mathrm{a}$ & $0.65 \pm 0.14 b$ & $0.26 \pm 0.02 \mathrm{a}$ \\
\hline $100 \%$ & $20.33 \pm 0.88 b$ & $2.67 \pm 0.33 a$ & $3.50 \pm 0.12 \mathrm{a}$ & $0.41 \pm 0.03 \mathrm{ab}$ & $0.16 \pm 0.04 a$ \\
\hline Total & 14.33 & 2.67 & 3.52 & 0.40 & 0.22 \\
\hline
\end{tabular}

Values are mean \pm Standard Error, values followed by the same alphabet(s) along the column are not significantly different at $\mathrm{p}>0.05$.

Table 3. Pearson's correlations among some agro-morphological parameters for 'TG x 2018-5E'

\begin{tabular}{|c|c|c|c|c|c|c|c|c|c|}
\hline & $\begin{array}{l}\text { Plant height } \\
\quad(\mathrm{cm})\end{array}$ & $\begin{array}{c}\text { Number } \\
\text { of } \\
\text { branches }\end{array}$ & $\begin{array}{c}\text { Petiole } \\
\text { length }(\mathrm{cm})\end{array}$ & $\begin{array}{l}\text { Leaf area } \\
\left(\mathrm{cm}^{2}\right)\end{array}$ & $\begin{array}{c}\text { Number of } \\
\text { pods per } \\
\text { plant }\end{array}$ & $\begin{array}{l}\text { Number } \\
\text { of seeds } \\
\text { per pod }\end{array}$ & $\begin{array}{l}\text { Length } \\
\text { of pods } \\
(\mathrm{cm})\end{array}$ & $\begin{array}{l}\text { Weight } \\
\text { of pod } \\
\text { (g) }\end{array}$ & $\begin{array}{c}\text { Weight } \\
\text { of dry } \\
\text { pod (g) }\end{array}$ \\
\hline $\begin{array}{l}\text { Plant height at } \\
\text { maturity }(\mathrm{cm})\end{array}$ & 1.00 & & & & & & & & \\
\hline $\begin{array}{c}\text { Number of } \\
\text { branches }\end{array}$ & 0.238 & 1.00 & & & & & & & \\
\hline $\begin{array}{l}\text { Petiole length } \\
(\mathrm{cm})\end{array}$ & 0.254 & 0.148 & 1.00 & & & & & & \\
\hline Leaf area $\left(\mathrm{cm}^{2}\right)$ & 0.107 & -0.249 & 0.167 & 1.00 & & & & & \\
\hline $\begin{array}{c}\text { Number of pods } \\
\text { per plant }\end{array}$ & 0.179 & $0.527^{*}$ & 0.074 & 0.032 & 1.00 & & & & \\
\hline $\begin{array}{c}\text { No. of seeds per } \\
\text { pod }\end{array}$ & -0.273 & $0.610^{\circ}$ & 0.256 & -0.373 & 0.191 & 1.00 & & & \\
\hline $\begin{array}{c}\text { Length of pods } \\
(\mathrm{cm})\end{array}$ & 0.163 & 0.323 & -0.029 & 0.055 & 0.415 & 0.035 & 1.00 & & \\
\hline Weight of pod $(\mathrm{g})$ & -0.468 & 0.168 & 0.016 & -0.328 & 0.003 & 0.323 & 0.242 & 1.00 & \\
\hline $\begin{array}{l}\text { Weight of dry pod } \\
(\mathrm{g})\end{array}$ & -0.361 & 0.441 & 0.090 & -0.137 & 0.074 & $0.593^{\circ}$ & 0.233 & $0.748^{* *}$ & 1.00 \\
\hline
\end{tabular}

${ }^{*}$ Correlation is significant at the 0.05 level (2-tailed); ${ }^{* *}$ Correlation is significant at the 0.01 level (2-tailed).

In 'TG x 2022-4E', length of pods was positive, significant $(\mathrm{P} \leq 0.05)$ and moderately correlated with number of branches at maturity (0.688). Leaf area at maturity was positive, highly significant $(\mathrm{P} \leq 0.01)$ and highly correlated with number of pods per plant. It is also positive, significant $(\mathrm{P} \leq 0.05)$ and moderately correlated with weight of pod (0.621). Plant height at maturity was positive, moderately correlated with length of petiole at maturity and weight of dry pod; although the correlation coefficient was not significantly different. Other parameters showed no significance and low associations with one another (Table 4). 
Daudu YOA et al. (2020). Not Sci Biol 13(1):10876

Table 4. Pearson's correlations among some agro-morphological parameters for 'TG x 2022-4E'

\begin{tabular}{|c|c|c|c|c|c|c|c|c|c|}
\hline Traits & $\begin{array}{c}\text { Plant height } \\
(\mathrm{cm})\end{array}$ & $\begin{array}{l}\text { Number of } \\
\text { branches }\end{array}$ & $\begin{array}{c}\text { Petiole } \\
\text { length } \\
(\mathrm{cm})\end{array}$ & $\begin{array}{l}\text { Leaf } \\
\text { area } \\
\left(\mathrm{cm}^{2}\right)\end{array}$ & $\begin{array}{c}\text { Number of } \\
\text { pods per } \\
\text { plant }\end{array}$ & $\begin{array}{l}\text { Number } \\
\text { of seeds } \\
\text { per pod }\end{array}$ & $\begin{array}{l}\text { Length } \\
\text { of pods } \\
(\mathrm{cm})\end{array}$ & $\begin{array}{c}\text { Weight } \\
\text { of pod } \\
(\mathrm{g})\end{array}$ & $\begin{array}{c}\text { Weight } \\
\text { of dry } \\
\text { pod (g) }\end{array}$ \\
\hline $\begin{array}{c}\text { Plant height } \\
(\mathrm{cm})\end{array}$ & 1.00 & & & & & & & & \\
\hline $\begin{array}{l}\text { Number of branches } \\
(\mathrm{cm})\end{array}$ & -0.034 & 1.00 & & & & & & & \\
\hline $\begin{array}{l}\text { Petiole length } \\
(\mathrm{cm})\end{array}$ & 0.526 & -0.443 & 1.00 & & & & & & \\
\hline $\begin{array}{c}\text { Leaf area } \\
\left(\mathrm{cm}^{2}\right)\end{array}$ & -0.205 & 0.463 & 0.076 & 1.00 & & & & & \\
\hline $\begin{array}{l}\text { Number of pods per } \\
\text { plant }\end{array}$ & -0.134 & 0.426 & 0.253 & $0.726^{* *}$ & 1.00 & & & & \\
\hline $\begin{array}{l}\text { Number of seeds per } \\
\text { pod }\end{array}$ & 0.347 & 0.377 & -0.123 & 0.316 & 0.269 & 1.00 & & & \\
\hline $\begin{array}{c}\text { Length of pods } \\
(\mathrm{cm})\end{array}$ & 0.258 & $0.688^{*}$ & -0.336 & 0.024 & 0.217 & 0.490 & 1.00 & & \\
\hline $\begin{array}{l}\text { Weight of pod } \\
(\mathrm{g})\end{array}$ & 0.246 & 0.292 & 0.347 & $0.621^{*}$ & 0.404 & 0.369 & 0.192 & 1.00 & \\
\hline $\begin{array}{l}\text { Weight of dry pod } \\
(\mathrm{g})\end{array}$ & 0.540 & 0.080 & 0.207 & -0.128 & -0.140 & -0.180 & 0.367 & 0.308 & 1.00 \\
\hline
\end{tabular}

${ }^{*}$ Correlation is significant at the 0.05 level (2-tailed); ${ }^{* *}$ Correlation is significant at the 0.01 level (2-tailed).

\section{Discussion}

The differences in plant height of the treated plant and control of both 'TG x 2018-5E' and 'TG x 2022$5 \mathrm{E}$ ' may be attributed to the stimulatory effect of $D$. stramonium seed extracts on the growth of soybean plant at medium (50\%) and high (100\%) concentrations. Similar findings have been reported by Daudu et al. (2020) where it was opined that notable increase of plant height may be attributed to the stimulatory effects of $D$. stramonium on the growth of maize plant at medium and high concentrations. Contrary to this, Stef et al. (2018) stated that the greatest reduction in plant height in the variants is recorded when the leaves extracts were applied to soybean. It was further stated that extracts from the roots had limited influence on the growth of soybean containing the lowest amount of allelopathic substances. In addition to this Kusuma et al. (2018), reported that the decrease in soybean plant height is caused by the disruption of growth hormone activation. The difference in this report might be due to difference in plant parts from which the extracts was obtained and possibly mode of extraction and solvent used; because phytochemical accumulation does vary from different plant parts.

The length of leaf petiole results showed significant increase in respect to the concentration of Datura seed extract application; thus, the extract had stimulatory effects on 'TG x 2018-5E' but seems to have inhibitory effects on petiole length of 'TG x 2022-4E'. Reduction in petiole length maybe as a result of reduced cell division caused by the allelopathic effect of D. stramonium (Awadallah et al., 2019, Daudu et al., 2020). Similarly, the increase in leaf area due to high concentration of Datura seed extracts which led to increased number of pods per plant and weight of pods per plant, might be attributed to increase in surface area for photosynthesis. Thus, high availability of energy for yield mobilization and production activities. The increased leaf area index in soybean varieties might be due to the stimulatory effects of the extracts. In 'TG x 2018-5E', the highest number of branches per plant obtained could be due to the fact that the extracts had stimulatory effects on this parameter rather than inhibitory effects. Such stimulatory effects may be due to high concentration of alkaloids or allelochemical present in the seeds of Datura stramonium which may have triggered the production of growth hormones in the variety. Contrary to this, Isda et al. (2013), reported that the presence of allelochemical compounds in the form of phenol will inhibit cytokinin activity; this barrier may cause disruptions in the shoot meristem part so that it can inhibit high growth in plants. The number of 
branches reported for all the treated crops ranged from 12 to 17 was higher than those of Halil et al. (2017) who reported that the average branch number per plant ranged from 2.3 to 3.6. This contrary might be due to variation in the genetic makeup of the soybean used in this study as well as environmental influence which may also influence the physical appearance of soybean.

Higher concentrations of Datura seed extract have greatly influenced the yield output of 'TG x 2018$5 \mathrm{E}$ ' by stimulating its number of pods and length, where it performed better than 'TG x 2022-4E'. Contrary to this, Scepanovic et al. (2007) stated that Datura stramonium expresses allelopathic effect on several species, reducing the yield of cereal crops and biodiversity of local flora. The difference in this result might be due to the fact that no plant extracts was used, many beneficial phytochemicals are hidden and must be extracted before their beneficial effects will become manifest. It is therefore more glaring that despite allelopathic potential of Datura; certain beneficial phytochemicals with stimulatory effects are present in the crop. The yield output of 'TG x 2022-4E' was inhibited by the seed extract thereby resulting to poor yield of the variety. Khan et al. (2015), also reported that plant population $/ \mathrm{m}^{2}$, plant height, number of branches per plant, filled pods per plant, unfilled pods per plant, 100 -seed weight and seed yield of soybean showed significant variations across the genotypes. The highest seed yield was attributed by the higher number of plant population $/ \mathrm{m}^{2}$, filled pods/plant and 100-seed weight. Malik et al. (2006) also observed high variability for seed yield in soybean genotypes; the highest length of pods recorded $(4.80 \mathrm{~cm})$ in 'TG x 2018-5E' at $100 \%$ concentration and the lowest recorded $(3.23 \mathrm{~cm})$ in 'TG x $2022-4 \mathrm{E}$ ' at $25 \%$ concentration. Also, the differences in grain yield and other morphological characters observed among the cultivars, is in consonance with the earlier findings of Ugur et al. (2005) who reported that morphological characters such as number of flowers, number of pods, date of harvest are dependent on the genetic constituent of the cultivars. Effects of aqueous seed extracts on some of the agro-morphological traits showed great association, this implies that such traits can be improved upon together. For example, increase in leaf areas in 'TG x 2022-4E' will lead to high surface area for photosynthesis, and consequently lead to more fruits and heavier fruits due to accumulation of more photosynthates (Daudu et al., 2020).

\section{Conclusions}

The study clearly indicates that the aqueous seed extracts of Datura stramonium contain allelochemicals that act as inhibitors and growth stimulators. The higher concentrations of seed extracts (50\% and 100\%) enhanced certain agro-morphological parameters. The study revealed the stimulatory effect of Datura stramonium seed extract on plant height, length of leaf petiole, leaf area and number of branches per plant. The yield output showed variation in terms of genotype; generally speaking, 'TG x 2018-5E' performed better in respect to the concentration of the extract than 'TG x 2022-4E', the seed extracts also stimulated some of their yield attributes when compared with the control. There is need for further research and observation on effects of Datura stramonium aqueous seed extracts on other traits like root development, length of internodes and pollen diameter of the soybean varieties.

\section{Authors' Contributions}

DOAY; Major supervision; FOA; Project administration and validation; AA; Data curation, writing review and editing; IAS; Methodology; SOO \& MAU; Field evaluation and Data collection. All authors read and approved the final manuscript. 


\section{Acknowledgements}

This research received no specific grant from any funding agency in the public, commercial, or not-forprofit sectors. However, the authors to acknowledge Bioscience Centre, International Institute of Tropical Agriculture (IITA), Ibadan, Oyo State and Upper Niger River Basin Development Authority (UNRBDA), Tudun Fulani, Minna, Niger State for supporting the research with experimental material (seeds) and experimental field.

\section{Conflict of Interests}

The authors declare that there are no conflicts of interest related to this article.

\section{References}

Adekunle AA, Chovwen A, Fatunbi AO (2005). Growing soybean commercially in Nigeria. A training manual IITA/OCDN/COL/TODEV, IITA, Ibadan, Nigeria, pp 15. https://hdl.handle.net/20.500.12478/3394

Alexander J, Diane B, Andrew C, Jean-Pierre C, Eugenia D, Alessandro D, ... Philippe V (2008). Tropane alkaloids (from Datura sp.) as undesirable substances in animal feed: Scientific opinion of the panel on contaminants in the food chain. The European Food Safety Authority Journal 691:2-55. https://doi.org/10.2903/sp

Awadallah D, Hussein YH, Mustafa WN (2019). Phytotoxic effects of thorn apple (Datura stramonium L.) seed aqueous extract on seed germination of some leguminous crops using Probit analysis. International Journal of Academic Multidisciplinary Research 3:7-12. https://doi.org/10.29329/IJIAAR.2020.238.10

Tamiru A, Bayih T, Chimdessa M (2016). Synergistic bio-efficacy of insectidal plants against bean bruchids (Zabrotes subfasciatus: Coleoptera) a major storage pests of common bean. Journal of Fertilizers \& Pesticides 7(2):1-8. https://doi.org/10.4172/2471-2728.1000171

Butnariu M (2012). An analysis of sorghum halepense's behaviour in presence of tropane alkaloids from Datura stramonium extracts. Chemistry Central Journal 6:1-7. https://doi.org/10.1186/1752-153X-6-75.

Daudu OAY, Falusi OA, Abubakar A, Abdulsalami H, Bello TS, Audu MAI (2020). Effects of aqueous leaf extracts of Datura stramonium on vegetative traits of selected maize (Zea mays L.) varieties in Nigeria. East Journal of Biotechnology and Genetics 2(3):31-35. https://doi.org/10.36349/easjbg.2020.v02i03.003.

FAO (1994). Food and Agricultural Organisation. Fats and Oil in human nutrition. Reports of a joint export consultant, Rome, FAO Food and Nutrition paper, No. 57.

Filemon E, Mokiti TT, Patrick AN (2013). Allelopathic effects of seed and leaf aqueous extracts of Datura stramonium on leaf chlorophyll content, shoot and root elongation of Cenchrus ciliaris and Neonotonia wightii. American Journal of Plant Sciences 4:2332-2339. http://dx.doi.org/10.4236/ajps.2013.412289

Ganesh S, Radha R, Jayshree N (2015). A review on phytochemical and pharmacological status of Datura. International Journal of Multidisciplinary Research and Development 2(4):602-605.

Gniazdowska A, Bogatek R (2005). Allelopathic interactions between plants, multisite action of allelochemicals. Acta Physiologiae Plantarum 27(3):395-407. http://dx.doi.org/10.1007/s11738-005-0017-3.

Halil B, Leyla G, Bihter O, Halis A (2017).The effects of growing seasons on some agronomic and quality characteristics of soybean varieties in mediteranean region in Turkey. Turkish Journal of Field Crops 22(2):187-196. https://doi.org/10.17557/tjfc.356213

Hiraoka N (1996). Genotypes and alkaloid contents of Datura metel varieties. Biological and Pharmaceutical Bulletin 19(8):1086-1089.

Isda MN, Siti F, Dan Rahmi F (2013). Potensi ekstrak daun gulma babandotan (Ageratum conyzoides L.) Terhadap perkecamibahan dan pertumbuhan Paspalum conjugatum Berg. Al-Kauniyah Jurnal Biologi 2(6):120-125. https://doi.org/10.15408/kauniyah.v6i2.2752

Khan MS, Karim AMA, Haque MM, Karim AJMS, Mian MAK (2015). Growth and dry matter partitioning in selected soybean (Glycine $\max$ L.) genotypes. Bangladesh Journal of Agricultural Research 40(3):333-345. https://doi.org/10.3329/bjar.v40i3.25409 
Kusuma D, Wardani SD, Rini B (2018). Allelochemical effects of Ageratum conyzoides L. leaf extract on soybean (Glycine $\max ($ L.) Merr. Or Grobogan) growth. Journal of Physics Conference Series 1025:012044. https://doi.org/10.1088/1742-6596/1025/1/012044

Mahnaz A, Hamid K, Reza A (2012). Acute Datura stramonium poisoning in east of Iran. A case series. Avicenna Journal of Phytomedicine 2(2):86-89. https://doi.org/10.22038/ajp.2012.37

Maibam RD, Meenakshi B, Paul SB, Sharma GD (2011). Neurotoxic and medicinal properties of Datura stramonium L. Review. Assam University Journal of Science and Technology: Biological and Environmental Sciences 7(1):139144.

Maibam SS, Konthoujam DN, Abhay KV, Naorem GS (2008). Effect of bioregulators on growth, yield and chemical constituents of soybean (Glycine max). Journal of Agricultural Science 3(4):151. https://doi.org/10.5539/jas.v3n4p151

Malik MFA., Qureshi AS, Ashraf M, Ghafoor A (2006). Genetic variability of the main yield related characters in soybean. International Journal of Agriculture and Biology 8(6):815-819.

Olorunsanya EO, Babatunde RO, Orebiyi JS, Omotosho JO (2009). Economic analysis of soyabeans production in Kwara State, North-central Nigeria. Global Approaches to Extension Practices: A Journal of Agricultural Extension 5(2). https://doi.org/10.4314/gaep.v5i2.53738

Oseni OA, Olarinoye CO, Amoo IA (2011). Studies on chemical compositions and functional properties of thornapple (Datura stramonium L.) Solanaceae. African Journal of Food Science 5(2):40-44. https://doi.org/10.5897/AJFS.9000274

Oyerinde RO, Otusanya OO, Akpor OB (2009). Allelopathic effect of Tithonia diversifolia on the germination, growth and chrophyll content of maize (Zea mays L.). Scientific Research and Essay 4(12):1553-1558.

Scepanovic M, Novak N, Baric K, Ostojic Z, Galzina N, Gorsic M (2007). Allelopathic effect of two weed species Abutilon theophrasti Med. and Datura stramonium L. on germination and early growth of corn. Agronomoski Glasmik 6:459-472.

Stef R, Lamandei M, Carabet A, Grozea L, Virteiu AM, Manea D (2018). Allelopathic influence of Datura stramonium extracts on the germination and growing of soy plants. Journal of Horticulture, Forestry and Biotechnology $22(2): 30-33$.

Ugur B, Mehmet S, Abdurrahim TG, Zek MT, Esvet A (2005). Forage and grain performances of soybean lines. Journal of Central European Agriculture 6(3):397-402.

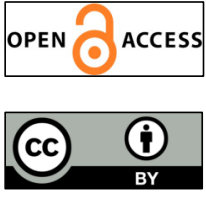

The journal offers free, immediate, and unrestricted access to peer-reviewed research and scholarly work. Users are allowed to read, download, copy, distribute, print, search, or link to the full texts of the articles, or use them for any other lawful purpose, without asking prior permission from the publisher or the author.

License - Articles published in Notulae Scientia Biologicae are Open-Access, distributed under the terms and conditions of the Creative Commons Attribution (CC BY 4.0) License.

(c) Articles by the authors; SHST, Cluj-Napoca, Romania. The journal allows the author(s) to hold the copyright/to retain publishing rights without restriction. 